\title{
Achieving sustainable coastal environment in Langkawi, Malaysia
}

\author{
Mazlin Bin Mokhtar1,2*, Minhaz Farid Ahmed1, Lee Khai Ern',2, Lubna Alam1, Goh Choo Ta1, Rahmah \\ Elfithri ${ }^{1}$, Jamil Tajam ${ }^{1,3}$ and Anthony Wong Kim Hooi ${ }^{4}$ \\ ${ }_{1}^{1}$ Institute for Environment and Development, Universiti Kebangsaan Malaysia, 43600 Bangi, Selangor, Malaysia \\ 2Jeffrey Sachs Center on Sustainable Development, Sunway University, Bandar Sunway, Selangor, Malaysia. \\ ${ }^{3}$ Ocean Research Conservation and Advances, UiTM Perlis, Perlis, Malaysia \\ ${ }^{4}$ The Frangipani Langkawi Resort and Spa, Jalan Teluk Baru Pantai Tengah, Langkawi, Kedah, Malaysia
}

${ }^{*}$ Corresponding author: mazlin@ukm.edu.my

\begin{abstract}
Despite many good policies and institutions, the coastal environment of Langkawi continues to deteriorate. This could be due to lack of effective governance as well as unregulated waste discharge. Evidences collected from the literature during 1996 to 2013 also revealed a significant increase in the concentrations of $\mathrm{Zn}\left(\mathrm{R}^{2}=0.78\right)$ and $\mathrm{Pb}\left(\mathrm{R}^{2}=0.12\right)$ in the sediment. This appears to be the result of large volume of terrestrial runoff that brings these metals originating from extensive anthropogenic activities. It is a vital indicator of coastal pollution. It is a matter of concern that in many cases Pb concentration in the sediment exceeded the world average value $20 \mu \mathrm{g} / \mathrm{g}$ as well as Canadian Interim Sediment Quality Standard of $35 \mu \mathrm{g} / \mathrm{g}$ for the coastal areas. Similarly, the metal pollution index (MPI) measured over a period of 2007 to 2009 in fish also indicated an increasing trend of pollution in Langkawi. The maximum MPI value (4.87) was recorded in Spanish mackerel. Since pollution of coastal environment has serious implications for marine biodiversity and health of seafood consumers, measures are required to address this problem. Use of constructed wetland might be effective in reducing the coastal pollution as this will filter the effluent and waste before their mixing with the coastal water. Furthermore, enabling the stakeholders to play the environmental stewardship role will ensure better governance of coastal ecosystem and effective implementation of policies, envisaging an improved monitoring of waste/effluent discharge into the coastal marine environment. These measures are among the actions necessary for achieving a sustainable coastal environment of Langkawi.
\end{abstract}

Keywords: Environmental degradation, Human health, Sustainable development, Langkawi

\section{Introduction}

Sustainable coastal environmental management requires integration of social, cultural, ecological and economic activities consistent with the goals of sustainable development (Stocker et al., 2012). University of Wollongong in Australia defined the coastal management theory proposed by Harvey and Caton (2003) as "the management of human activities and sustainable use of Australia's coastal resources in order to minimize adverse impacts on coastal environments now and in the future" (Stocker et al., 2012). Meanwhile, adaptive and collaborative approaches of coastal management have integrated with shared governance and the focus has been on public participation, ecological awareness, improved integration between the various sectors, less engineered solutions and, in essence, to the concept of sustainable development (Stocker et al., 2012).

Coastal zones are the link between land and the sea, and are unique areas characterized by high marine biodiversity. They are environmentally sensitive and economically valuable resources. Coastal zones provide vitally important ecosystem services such as seafood, protection from natural hazards, ecotourism and climate change mitigation among others. They are also of great aesthetic value and a part of our cultural heritage. Activities such as aquaculture and tourism are beneficial to the economy and human well-being, but if not managed effectively they can also place significant pressures on coastal zones through biodiversity loss, contamination by hazardous substances, introduction of non-indigenous species and marine litter (EU, 2014). It has been highlighted by the United Nations (2017) that the adverse impacts of climate change (ocean acidification), overfishing and marine pollution are jeopardizing the recent gains in protecting the world's oceans as required under Sustainable Development Goal (SDG) 14. The target 14.1 clearly states that by 2025 countries must take measures to prevent and significantly reduce marine pollution of all kinds, in particular from landbased activities, including marine debris and nutrient pollution.

Langkawi Island (Figure 1) is one of the tourist hotspots in Malaysia which was declared a UNESCO Global Geopark in 2007 (Chan, 2015). The island received more than 43,000 Chinese tourists in the first quarter of 2016 which was an increase of $26.7 \%$ from 2015 (Haizhou, 2017). Management of solid waste and effluents from the hotels and restaurants with the increasing number of tourists is a challenge to maintain the environmental quality, especially the aquatic ecosystem (Abdullah et al., 2014). Agriculture, aquaculture, fishing, boats, ferries and cargoes are 
contributing to the problem of pollution. Apart from nonpoint sources, manufacturing industries $(47.15 \%)$, sewage treatment plants (46.74\% inclusive of 736 Network Pump Stations), animal farms (3.72\%) and agro-based industries (2.39\%) have degrading effect on the environment (UKEssays, 2015).

Kamaruzzaman et al. (2011) surveyed the problem of pollution of the Langkawi coastal water and reported higher concentration of $\mathrm{Pb}(41.87 \pm 7.30 \mu \mathrm{g} / \mathrm{g})$ and $\mathrm{Cu}$ $(11.19 \pm 5.2 \mu \mathrm{g} / \mathrm{g})$. Kamaruzzaman et al. (2011a) also reported higher concentrations of $\mathrm{Pb}, \mathrm{Cu}$ and $\mathrm{Zn}$ in the bottom sediments of Langkawi. The $\mathrm{Pb}$ concentration in the sediment of Langkawi coastal area was much higher than the world average concentration of $20 \mu \mathrm{g} / \mathrm{g}$ (Kamaruzzaman et al., 2011). Since metal concentration in the sediment is considered as one of the potential indicators of aquatic pollution, this review explored the published data on the trend of metal concentration in sediment and the health risk from consumption of contaminated fish. Although Malaysia has many good policies such as Environmental Quality Act 1974 and Fisheries Act 1985 to protect the marine environment, yet the problem of pollution from anthropogenic activities has continued to grow. This study was undertaken to examine the problem from secondary sources of information and suggest measures for sustainable management of the coastal environment of Langkawi.

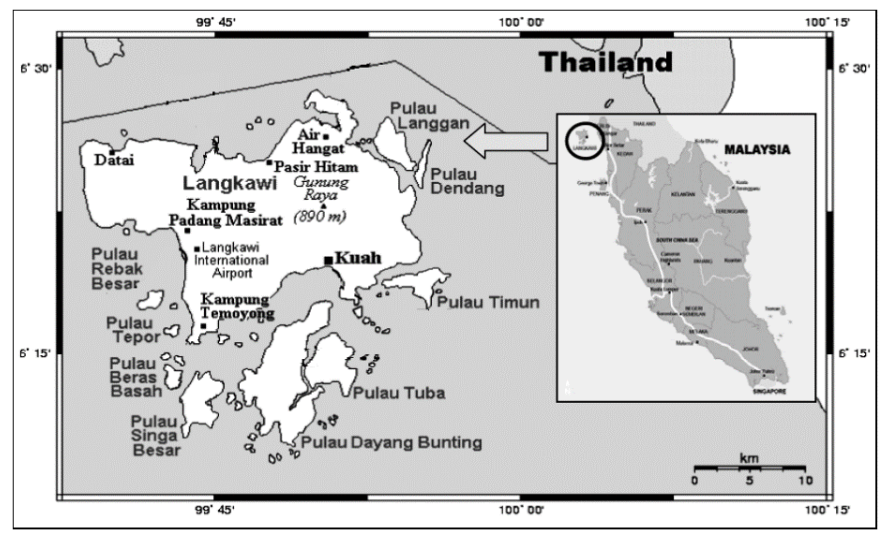

Figure 1. Study area in Langkawi coastal zone

(Kamaruzzaman et al., 2011)

Human health risk from polluted coastal environment

Seafood is generally recognized as a healthy food choice, but when contaminated it can produce harmful effects on human health. The health benefits of fish consumption are based on several research investigations (Kinsella et al., 1990; Oomen et al., 2000). Much work has recently been done on improving dose calculation for non-human organisms, particularly as part of the FASSET Programme (Prohl, 2003; Brown et al., 2004). Many studies have estimated the human daily intake and uptake of organochlorine pesticides (OCPs), polychlorinated biphenyls (PCBs), polybrominated diphenyl ethers (PBDEs), polycyclic aromatic hydrocarbons (PAHs), and toxic trace elements-mercury $(\mathrm{Hg})$, chromium $(\mathrm{Cr})$, cadmium (Cd), and arsenic (As) due to consumption of fish from Taihu Lake in China, and the associated carcinogenic health risks posed by these contaminants (Yu et al., 2014). In one investigation Chu et al. (2013) assessed the potential risk of human exposure to carcinogenic leucomalachite green (LMG) due to fish consumption in Taiwan. In order to limit the exposure to contaminants while maximizing the benefits of seafood consumption, a number of quantitative and qualitative risk-benefit analyses have been conducted (Strandberg et al., 2016; Anishchenko et al., 2017; Vilavert et al., 2017).

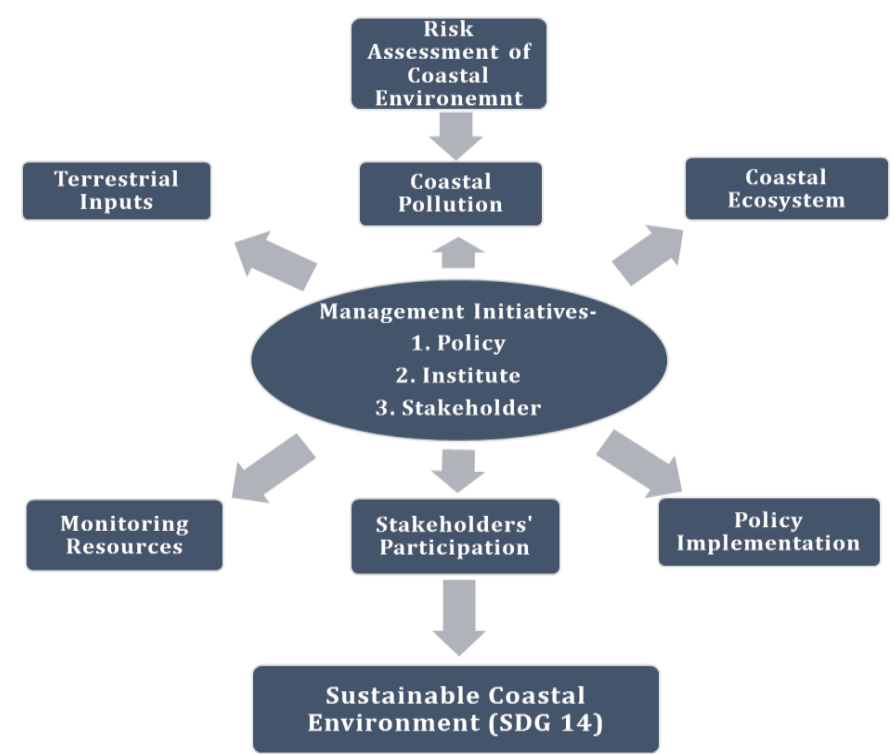

Figure 2. Conceptual framework for achieving sustainable coastal environment

Table 1. Mean concentrations of metals in municipal solid waste sample of Langkawi

\begin{tabular}{lc}
\hline Metals & Concentration $(\mathrm{mg} / \mathrm{kg})$ \\
\hline Sodium $(\mathrm{Na})$ & 279.3 \\
Potassium(K) & 615.1 \\
Calcium (Ca) & 374.37 \\
Cadmium (Cd) & 0.105 \\
Copper (Cu) & 3.072 \\
Aluminium (Al) & 3.227 \\
Nickel (Ni) & 1.588 \\
Iron (Fe) & 410.6 \\
Lead (Pb) & 12.56 \\
Mercury (Hg) & 0.106 \\
Tin (Sn) & 0.071 \\
Zinc (Zn) & 0.297 \\
Chromium (Cr) & 3.651 \\
Arsenic (As) & 0.082 \\
Cobalt (Co) & 0.069 \\
Manganese (Mn) & 2.546 \\
\hline
\end{tabular}

\section{Terrestrial inputs}

Lead $(\mathrm{Pb})$ in higher concentration in the aquatic environment is considered a serious risk to health because of its toxicity (Islam et al., 2015). On the other hand, $\mathrm{Cu}$ and $\mathrm{Zn}$ are considered as micronutrients in trace amounts (Zahir et al., 2011) but their higher concentrations are also toxic for living organisms (Mohiuddin et al., 2011; Islam et al., 2015). Pollution of the water with metals is a threat to survival of aquatic organisms. Although many of the metals are naturally found in the environment in small concentrations, but the development activities in the rapidly industrializing 
regions have contributed to increasing their load, leading to the serious problem of pollution of the rivers, lakes and sea.

Interestingly, although the mean concentration of $\mathrm{Pb}$ is $12.56 \mathrm{mg} / \mathrm{kg}$ in the municipal solid waste, it is lower compared to other metals in Langkawi (Table 1). However, the discharge of $\mathrm{Pb}$ in the water produces toxic effects and non-biodegradable characteristics. The landfill leachate contains $0.125 \mathrm{mg} / \mathrm{L}$ of $\mathrm{Pb}$ in the municipal solid waste of Langkawi which is higher than $\mathrm{Cu}(<0.01 \mathrm{mg} / \mathrm{L})$ (Table 2).

Table 2. Leachate composition of municipal solid waste in Langkawi

\begin{tabular}{lc}
\hline Test Parameter & Langkawi Island \\
\hline Temperature $\left({ }^{\circ} \mathrm{C}\right)$ & $30.2\left(^{\circ} \mathrm{C}\right)$ \\
pH & 8.65 at $30.02\left({ }^{\circ} \mathrm{C}\right)$ \\
Colour & Hazen Black \\
BOD 5 at $20\left({ }^{\circ} \mathrm{C}\right)(\mathrm{mg} / \mathrm{L})$ & 11,460 \\
COD $(\mathrm{mg} / \mathrm{L})$ & 40,400 \\
Total nitrogen (mg/L) & 1,265 \\
Ammonical nitrogen (mg/L) & 903.2 \\
Phosphate (mg/L) & 32.1 \\
Sulphate as SO4 2- (mg/L) & 135.4 \\
Sulphide (mg/L) & 1.7 \\
Alkalinity as CaCO3 (mg/L) & 297.2 \\
Chromium hexavalent (mg/L) & 0.161 \\
Chromium trivalent $(\mathrm{mg} / \mathrm{L})$ & 0.064 \\
Sodium (mg/L) & 1620 \\
Silver (mg/L) & $<0.01$ \\
Mercury (mg/L) & $<0.05$ \\
Magnesium (mg/L) & 170.6 \\
Cadmium (mg/L) & $<0.01$ \\
Arsenic (mg/L) & $<0.01$ \\
Cyanide (mg/L) & 2.85 \\
Lead (mg/L) & 0.125 \\
Copper (mg/L) & $<0.01$ \\
Manganese (mg/L) & 0.214 \\
Zinc (mg/L) & 0.457 \\
Nickel (mg/L) & 0.205 \\
Cobalt (mg/L) & $<0.01$ \\
Phenol (mg/L) & 0.94 \\
Total chromium as Cr (mg/L) & 0.225 \\
\hline
\end{tabular}

Kamaruzzaman et al. (2011) and Wood et al. (1997) have reported that the leaded gasoline used in the boats, ships and many business activities in Malaysia is an important source of atmospheric $\mathrm{Pb}$. Leakage of oil from ships also releases $\mathrm{Pb}$ in the sea water.

\section{Heavy metals in coastal water and sediment}

Highest $\mathrm{Pb}$ concentration $(43.28 \pm 8.95 \mu \mathrm{g} / \mathrm{g})$ in the sediment of Langkawi coastal area was observed in 2011. This value exceeded the Canadian Interim Sediment Quality Guideline $(35 \mu \mathrm{g} / \mathrm{g})$. The lowest concentration was $1 \mu \mathrm{g} / \mathrm{g}$ in 1996 (Table 3). The interim sediment quality indicates the concentration above which adverse biological effects are expected to occur. Accordingly, the highest $\mathrm{Cu}$ concentration $(29.22 \pm 8.84 \mu \mathrm{g} / \mathrm{g})$ in the sediment during 1999 was below the interim sediment standard guideline $(35.7 \mu \mathrm{g} / \mathrm{g})$. Similarly, the highest Zn concentration of $78.9 \pm 26.63 \mu \mathrm{g} / \mathrm{g}$ was also below the Canadian Interim Sediment Standard guideline that provides concentration of $123 \mu \mathrm{g} / \mathrm{g}$ (Table 3 ).
Table 3. Selected metals in sediment of Langkawi coastal area from 1996-2013

\begin{tabular}{|c|c|c|c|}
\hline Year and Source & $\begin{array}{c}P b \\
(\mu \mathrm{g} / \mathrm{g})\end{array}$ & $\begin{array}{c}\mathrm{Cu} \\
(\mu \mathrm{g} / \mathrm{g})\end{array}$ & $\begin{array}{c}\mathrm{Zn} \\
(\mu \mathrm{g} / \mathrm{g})\end{array}$ \\
\hline 1996 (Mokhtar et al.,2001) & 1 & & 6 \\
\hline 1999 (Yap et al., 2002) & $\begin{array}{c}23.32 \pm \\
3.39\end{array}$ & $\begin{array}{c}29.22 \pm \\
8.84\end{array}$ & - \\
\hline 2005 (Jalal et al., 2009) & $\begin{array}{l}1.94 \pm \\
0.05\end{array}$ & - & - \\
\hline 2008 (Kamaruzzaman et al., 2011) & $\begin{array}{c}41.87 \pm \\
7.30\end{array}$ & $\begin{array}{c}11.19 \pm \\
5.2\end{array}$ & - \\
\hline 2009 (Zahir et al., 2011) & $\begin{array}{c}30.97 \pm \\
3.26\end{array}$ & $\begin{array}{c}27.82 \pm \\
10.03\end{array}$ & $\begin{array}{l}78.9 \pm \\
26.63\end{array}$ \\
\hline 2011 (Kamaruzzaman et al., 2011a) & $\begin{array}{c}43.28 \pm \\
8.95\end{array}$ & $\begin{array}{c}8.79 \pm \\
2.72\end{array}$ & 63.5 \\
\hline 2013 (Tajam and Kamal, 2013) & $\begin{array}{c}5.29 \pm \\
3.47\end{array}$ & - & $\begin{array}{l}66.82 \\
\pm 4.86\end{array}$ \\
\hline Dutch TV ${ }^{1}$ (Lundy et al., 2017) & 85 & 36 & 140 \\
\hline Dutch IV ${ }^{2}$ (Lundy et al., 2017) & 530 & 190 & 720 \\
\hline Canadian ISQG ${ }^{3}$ (Lundy et al., 2017) & 35 & 35.7 & 123 \\
\hline Canadian PEL (Lundy et al., 2017) & 91.3 & 197 & 315 \\
\hline \multicolumn{4}{|c|}{$\begin{array}{l}{ }^{1} \text { Target value- indicates the level that must be achieved to fully recover the } \\
\text { functional properties of the soil/sediment for humans, and plant and animal life; } \\
\text { Intervention value- indicates when the functional properties of the soil/sediment } \\
\text { for humans, and plant and animal life, is seriously impaired or threatened; } \\
\text { 3Interim sediment quality guideline- represents the concentration below which } \\
\text { adverse biological effects are expected to occur rarely; } \\
{ }^{4} \text { Probable effect level- defines the level above which adverse biological effects are } \\
\text { expected to occur frequently. }\end{array}$} \\
\hline
\end{tabular}

The increasing trend of $\mathrm{Pb}$ during 1996-2013, although not significant $\left(\mathrm{R}^{2}=0.12\right.$; Figure 3$)$, indicates continuous accumulation of this metal in the sediment of Langkawi coastal area. This is due to discharge of nonresistant fraction mostly of anthropogenic origin (Yap et al., 2002). Several studies have reported $\mathrm{Pb}$ from the extensive man-made activities, but the sources of $\mathrm{Cu}$ and $\mathrm{Zn}$ are both anthropogenic and terrigenous. The sharply increasing trend of $\mathrm{Zn}\left(\mathrm{R}^{2}=0.78\right)$ concentration in the sediment during 19962013 might be influenced by terrigenous as well as terrestrial runoff. On the other hand, the decreasing trend of $\mathrm{Cu}\left(\mathrm{R}^{2}=0.34\right)$ could be due to improved effluent treatment before mixing of fresh water with sea water. Yap et al. (2002) also reported lower non-resistant fraction of $\mathrm{Cu}$ in the coastal area of Langkawi. Since metal accumulation in the sediment is one of the important indicators of aquatic environmental pollution, so the increasing trend of $\mathrm{Pb}$ and $\mathrm{Zn}$ concentrations in the sediment suggests increasing pollution in the areas.

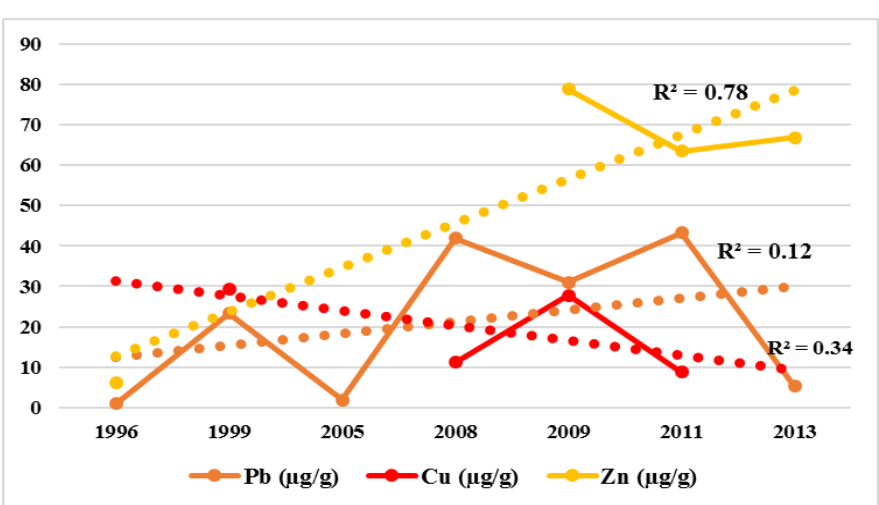

Figure 3. Trend of metals in sediment of Langkawi coastal area from 1996-2013 
Kamaruzzaman et al. (2011a) reported that the mean $\mathrm{Pb}$ concentration $(41.87 \mu \mathrm{g} / \mathrm{g})$ was two-fold higher than the world average shale value of $20 \mu \mathrm{g} / \mathrm{g}$, while Cu was lower than the world average value of $45 \mu \mathrm{g} / \mathrm{g}$. The possible main sources of $\mathrm{Pb}$ and $\mathrm{Cu}$ were anthropogenic and terrigenous. The enrichment factor analysis reflected moderate metal pollution in the Langkawi coastal area with increasing deposition rate. $\mathrm{Pb}$ - enriched gasoline used in ships and boats and its spillage during transport and other sea-based operations are the major sources of $\mathrm{Pb}$ in the marine environment of Langkawi (Kamaruzzaman et al., 2002). The recent and prehistoric man-made activities have attributed the higher level of $\mathrm{Pb}$ concentration in the sediments to its non-biodegradable characteristics as well as $\mathrm{Pb}$ accumulation and retention in the sediment for extended periods. The higher $\mathrm{Pb}$ accumulation in the sediment might also be due to extensive fishing activities and transport of seafood. Movement of cargo and tourist ferries between Langkawi Island and the mainland has been rising and thus possible leakage of oil during navigation should be monitored. Furthermore, cleaning and painting of the boats also drains out $\mathrm{Pb}$ in the seawater which gets deposited in the sediment (Kamaruzzaman et al., 2011a). This is in addition to the atmospheric $\mathrm{Pb}$ deposition, the main source of which is emission of leaded petrol from the automobile exhaust (Huntzicker et al., 1975). Wood et al. (1997) and Kamaruzzaman et al. (2011) have also highlighted the contribution of exhaust emission of leaded gasoline from the large vessels to higher $\mathrm{Pb}$ concentration in the sediment in Langkawi.

Activities in ports and jetties such as cleaning of boats and ships, ballasting, painting and repairing are sources of elevated $\mathrm{Cu}$ in the aquatic environment. Antifouling paint used for boats and ships along with scrapping of paint also releases $\mathrm{Cu}$ in the aquatic environment. Moreover, the transportation of fishery products for which jetties are extensively used might have contributed to increased $\mathrm{Cu}$ concentration in the marine environment (Kamaruzzaman et al., 2006). The possibility of decomposition of organic matter in the muddy bottom of Langkawi coastal areas by benthic organisms releasing $\mathrm{Cu}$ locked in the sediment cannot be ruled out (Yap et al., 2003a; Kamaruzzaman et al., 2011). Kamaruzzaman et al. (2011a) also reported that $\mathrm{Pb}, \mathrm{Cu}$ and $\mathrm{Zn}$ concentrations were higher near estuaries than the offshore areas, and that there was a correlation between higher metal concentration with lower particle size. In the estuarine areas, there were many sources of pollution such as industrial discharge and other anthropogenic activities in addition to natural weathering resulting in higher accumulation of metals in the sediment. Of course, this is strongly influenced by the dynamics of forces in the intertidal regions.

The dominant sources of $\mathrm{Cu}$ in the aquatic environment of Langkawi are effluents from industries and human settlements. Moreover, the mangrove swamps can also release metal residues through erosion of accumulated organic matter. The persistence of $\mathrm{Pb}, \mathrm{Cu}$ and $\mathrm{Zn}$ in the aquatic environment has devastating effects when in higher concentration (Kamaruzzaman et al., 2011). High $\mathrm{Cu}$ concentration of $1609.8 \mu \mathrm{g} / \mathrm{L}$ (Zulfigar et al., 2013) reported in 2013 represented a drastic increase from its value of 45$125 \mu \mathrm{g} / \mathrm{L}$ noticed in 2005 (Wong et al., 2005) (Table 4). This can be linked to several anthropogenic activities.

Table 4. Heavy metal in coastal water of Langkawi

\begin{tabular}{|c|c|c|c|c|c|c|}
\hline Source & $\begin{array}{c}\mathrm{Cu} \\
(\mu \mathrm{g} / \mathrm{L})\end{array}$ & $\begin{array}{c}\text { Cd } \\
(\mu \mathrm{g} / \mathrm{L})\end{array}$ & $\begin{array}{c}\mathrm{Cr} \\
(\mu \mathrm{g} / \mathrm{L})\end{array}$ & $\begin{array}{c}\mathrm{Ni} \\
(\mu \mathrm{g} / \mathrm{L})\end{array}$ & $\begin{array}{c}\mathrm{Pb} \\
(\mu \mathrm{g} / \mathrm{L})\end{array}$ & $\begin{array}{c}\mathrm{Zn} \\
(\mu \mathrm{g} / \mathrm{L})\end{array}$ \\
\hline $\begin{array}{l}\text { (Wong et al., } \\
2005 \text { ) }\end{array}$ & $45-125$ & $85-140$ & 4 of & , & $\begin{array}{l}570- \\
935\end{array}$ & $\begin{array}{l}130- \\
185\end{array}$ \\
\hline $\begin{array}{l}\text { (Zulfigar et } \\
\text { al., 2013) }\end{array}$ & 1609.8 & 0.072 & 13.23 & 5.57 & 0.64 & 70.91 \\
\hline
\end{tabular}

The metal profile in Porites corals from Langkawi also demonstrates an alarming increase in $\mathrm{Pb}$ concentration. In these corals the Pb concentration was $24.78 \mu \mathrm{g} / \mathrm{g}$ in 1996 , while in 2014 the concentration was as high as $119.42 \mu \mathrm{g} / \mathrm{g}$, indicating a trend of increasing pollution of Langkawi marine environment (Table 5). Similarly, higher Zn concentration $(118 \mu \mathrm{g} / \mathrm{g})$ in 2009 in the Langkawi coastal area also indicates the growing problem of pollution there. This seems to be due to terrestrial runoff from Sumatera and west coast of Peninsular Malaysia (Lee and Mohamed, 2009). The extent of the problem can be imagined from the fact that in 1996 the concentration of $\mathrm{Zn}$ was $16.22 \mu \mathrm{g} / \mathrm{g}$. However, $\mathrm{Sr}$ and $\mathrm{Ca}$ in the coral skeleton are related to $\mathrm{Zn}$ concentration, and concentration of both these minerals ( $\mathrm{Sr}$ and $\mathrm{Ca}$ ) in corals tend to decrease when $\mathrm{Zn}$ concentration increases more than $50 \mu \mathrm{g} / \mathrm{g}$ (Lee and Mohamed, 2009). Although coral is an important indicator for a marine biomonitoring program, but there is not much published data on this aspect in Malaysia.

Table 5. Metal concentration $(\mu \mathrm{g} / \mathrm{g})$ in the Porites corals of Langkawi coastal area

\begin{tabular}{lccc}
\hline \multicolumn{4}{c}{ Year and Source } \\
\hline Metals & $\begin{array}{c}\mathbf{1 9 9 6} \\
\text { (Mokhtar et } \\
\text { al., 2001) }\end{array}$ & $\begin{array}{c}\mathbf{2 0 0 9} \\
\text { (Kamaruzzaman } \\
\text { et al., 2011a) }\end{array}$ & $\begin{array}{c}\mathbf{2 0 1 4} \\
\text { (Bakri, 2014) }\end{array}$ \\
\hline $\mathrm{Pb}$ & 24.78 & - & 119.42 \\
$\mathrm{Zn}$ & 16.22 & 118.03 & - \\
$\mathrm{Mg}$ & - & 936.75 & - \\
$\mathrm{Sr}$ & - & 4478.38 & - \\
$\mathrm{Cd}$ & 2.56 & - & 11.8 \\
$\mathrm{Ni}$ & 3.22 & - & - \\
$\mathrm{Cr}$ & 4.78 & - & - \\
$\mathrm{Cu}$ & - & - & 43.85 \\
$\mathrm{Mn}$ & 3.89 & - & - \\
\hline
\end{tabular}

In many countries a great deal of attention has been given to this topic and corals are considered useful as a tracer of pollutants in the marine environment (Shen and Boyle, 1987; Bastidas and García, 1999). Since coral reefs are widely distributed in the tropical regions (Lee and Mohamed, 2009), hence this study on coral, water and sediment quality would provide useful information for determining the chemical pollution in the coastal water of not only Langkawi but the whole country and other tropical regions. The highest $\mathrm{Pb}$ concentration in the sediment of Langkawi coastal area was observed to be $43.28 \pm 8.95 \mu \mathrm{g} / \mathrm{g}$ during 2011 that crossed the value given under Canadian Interim Sediment Quality Guideline where maximum concentration is $35 \mu \mathrm{g} / \mathrm{g}$ while the minimum is only $1 \mu \mathrm{g} / \mathrm{g}$ in 1996 (Table 1 ). 
Table 6. Concentration of metals $(\mu \mathrm{g} / \mathrm{g})$ in fish species sampled from Langkawi

\begin{tabular}{|c|c|c|c|c|c|c|c|c|}
\hline Fish Name & Scientific Name & $\begin{array}{c}\text { Copper } \\
(\mathrm{Cu})\end{array}$ & $\begin{array}{l}\text { Manganese } \\
(\mathrm{Mn})\end{array}$ & $\begin{array}{l}\text { Zinc } \\
\text { (Zn) }\end{array}$ & $\begin{array}{l}\text { Cadmium } \\
\text { (Cd) }\end{array}$ & $\begin{array}{l}\text { Lead } \\
(\mathrm{Pb})\end{array}$ & $\begin{array}{c}\text { Mercury } \\
(\mathrm{Hg})\end{array}$ & Reference \\
\hline Golden snapers & Epinephelus sexfasciatus & 11.55 & 19.95 & 49.39 & $0.3(0.8)$ & 1.00 & $0.008(0.02)$ & \multirow{8}{*}{$\begin{array}{c}\text { (Irwandi } \\
\text { and Farida, } \\
\text { 2009) }\end{array}$} \\
\hline Marine catfishes & $\begin{array}{l}\text { Lutianus } \\
\text { agentimaculatus }\end{array}$ & 12.07 & 21.81 & 38.63 & 0.90 & 1.00 & 0.04 & \\
\hline Groupers & Cynoglossus lingua & 11.48 & 17.85 & 38.70 & 0.20 & 1.10 & nd & \\
\hline $\begin{array}{l}\text { Spanish } \\
\text { mackerels }\end{array}$ & Scolidon sorrakowah & 11.74 & 20.13 & 38.81 & 0.30 & 1.00 & nd & \\
\hline $\begin{array}{l}\text { Threadfin } \\
\text { breams }\end{array}$ & $\begin{array}{l}\text { Scomberomorus } \\
\text { commersoni }\end{array}$ & 12.60 & 17.75 & 37.23 & 0.20 & 0.90 & 0.03 & \\
\hline Pike and conger & Rastrelliger kanagurta & 12.68 & 24.35 & 38.95 & 0.30 & 0.80 & 0.02 & \\
\hline $\begin{array}{l}\text { Indian } \\
\text { mackerels }\end{array}$ & Psettodes crumei & 13.95 & 16.8 & 34.33 & 0.30 & 0.90 & 0.02 & \\
\hline $\begin{array}{l}\text { Pseudo } \\
\text { rhombus }\end{array}$ & Arius cumatranus & 12.75 & 16.8 & 38.70 & 0.20 & 0.90 & 0.02 & \\
\hline Bigeye Scad & Selar crumenophthalmus & 1.91 & 0.46 & 27 & 0.029 & 0.066 & $<0.05$ & \multirow{6}{*}{$\begin{array}{l}\text { (Agusa et } \\
\text { al., 2005) }\end{array}$} \\
\hline $\begin{array}{l}\text { Doublelined } \\
\text { Tonguesole }\end{array}$ & Paraplagusia bilineata & 1.35 & 0.398 & 18.9 & 0.019 & 0.03 & 0.09 & \\
\hline Redtail Scad & Decapterus kurroides & 3.32 & 0.323 & 33.1 & 0.098 & 0.026 & 0.05 & \\
\hline Shortfin Scad & Decapterus macrosoma & 3.48 & 0.539 & 29.1 & 0.162 & 0.051 & 0.06 & \\
\hline Torpedo Scad & Megalaspis cordyla & 2.21 & 0.383 & 17.9 & 0.203 & 0.026 & 0.1 & \\
\hline $\begin{array}{l}\text { Yellowfin } \\
\text { Seabream }\end{array}$ & Acanthopagrus latus & 1.31 & 0.588 & 33.6 & 0.059 & 0.072 & 0.31 & \\
\hline
\end{tabular}

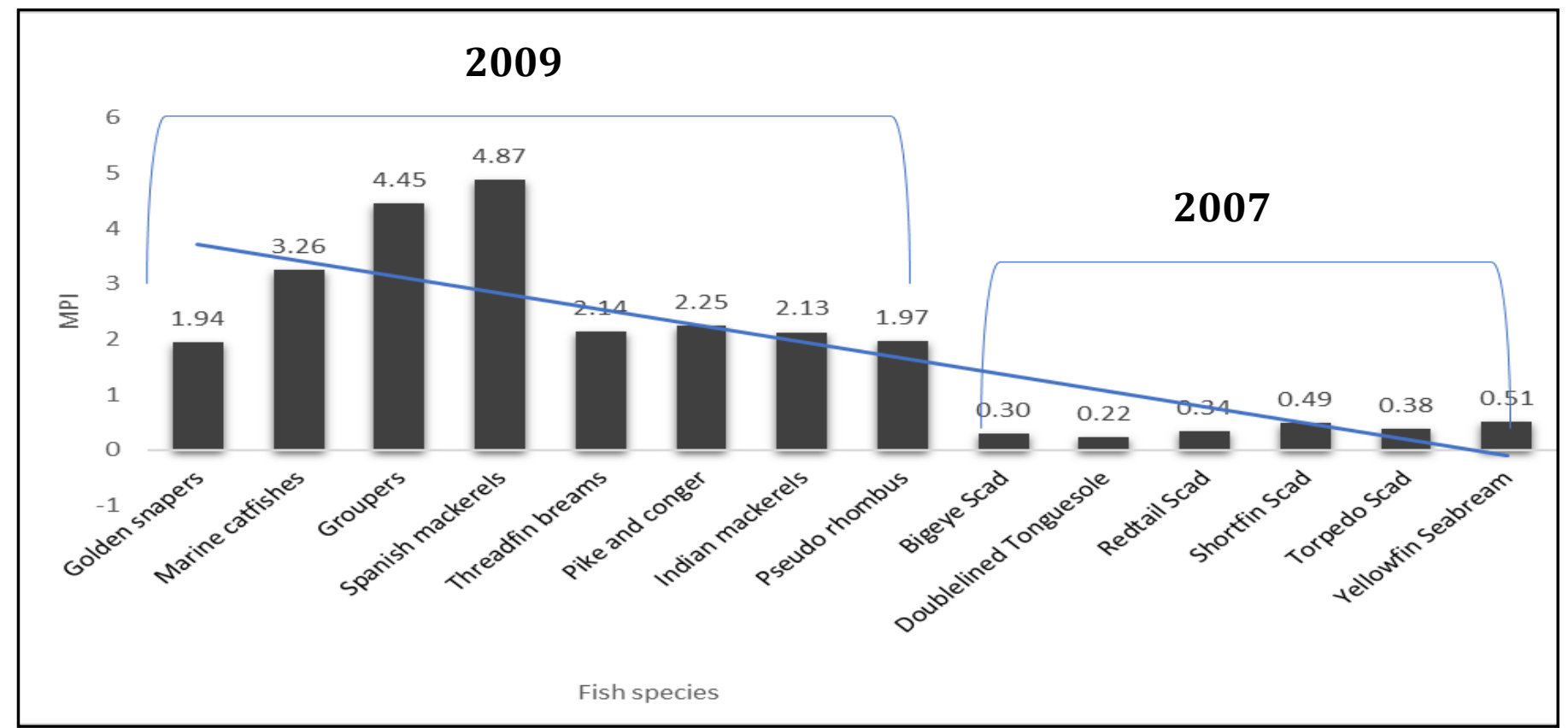

Figure 4. Calculated values of Metal Pollution Index for selected fish in Langkawi

Accordingly, the highest $\mathrm{Cu}$ concentration of $29.22 \pm 8.84 \mu \mathrm{g} / \mathrm{g}$ in the sediment during 1999 was below the interim sediment standard guideline $(35.7 \mu \mathrm{g} / \mathrm{g})$. Similarly, the highest $\mathrm{Zn}$ concentration $(78.9 \pm 26.63 \mu \mathrm{g} / \mathrm{g})$ was also below the Canadian Interim Sediment Standard Guideline, $123 \mu \mathrm{g} / \mathrm{g}$ (Table 1).

\section{Chemical contamination threatens fisheries sector}

The emerging fisheries sector of Malaysia is under threat because of chemical contamination both in the surface water and the sediment. Several studies have reported that the contamination by polycyclic aromatic hydrocarbon (PAHs) in the rivers, coastal areas and oceans is mainly due to poor management of the industries (Zakaria et al., 2002). Aquaculture production has increased from 73262 tons in 1981 to 581043 tons in 2010 but consumption of contaminated fish poses risk to human health (Mirsadeghi et al., 2011; Retnam et al., 2013). Strait of Malacca provides almost $70 \%$ fish production in the country but there are reports of contamination of some food fish with trace elements (Table 6) (Agusa et al., 2005; Alina et al., 2012). 
Several studies were conducted on the chemical contamination of fish in Malaysia. The level of contamination varied widely with the region and is mainly linked to industries. One of the studies reported that the concentrations of copper $(\mathrm{Cu})$, cadmium (Cd), zinc ( $\mathrm{Zn})$, lead $(\mathrm{Pb})$ and nickel $(\mathrm{Ni})$ were different in tilapia caught from Langat River and Engineering Lake in Bangi, Selangor (Taweel et al., 2013). Similarly, a study on the Kuantan estuary revealed that the water quality of the river water was degraded due to increase in industrialization and urbanization in Pahang (Jalal et al., 2012). Reports have also appeared (Yap et al., 2003, 2003b; Hajeb et al., 2009) that have raised concern about the polychlorinated biphenyl (PCB) and methyl mercury contamination of fish due to industrial discharges in the country.

Langkawi Island is considered as one of the most popular tourist destinations in the country but it is struggling with environmental problems due to extensive economic growth, tourism activities and over-exploitation of resources. Pollution is not only damaging the marine ecosystem but also threatening the human health by way of consumption of contaminated fish. Table 1 summarises the available data on concentration of some chemicals in seafood species sampled in Langkawi in 2007 and 2009. Regardless of the type of species, the overall metal content in fish muscle of the analysed species was compared using the Metal Pollution Index (MPI) calculated using the following formula (Alam et al., 2015):

$\mathrm{MPI}=(\mathrm{Cf} 1 \times \mathrm{Cf} 2 \times \cdots \times \mathrm{Cfn})^{1 / \mathrm{n}}$

Where, $C f n$ is the concentration of the metal $n$ in the sample. MPI of the organisms was calculated by obtaining the $n$-root from the $C f n$ that was obtained for all the metals.

MPI values are given in Figure 4. It is evident that the maximum value of MPI (4.87) was found in Spanish mackerel and minimum (0.22) in Double-lined Tongue-sole. There is a clear increasing trend of MPI value from 2007 to 2009 , indicating the growing problem of pollution in Langkawi. MPI values in 2009 were comparatively higher than the calculated values of MPI in fish species from other places (Azevedo et al., 2012; Alam et al., 2015; Ghani, 2015). This should be a matter of concern for regulatory agencies as much as the consumers.

\section{Role of constructed wetland in addressing coastal pollution}

With the rapid developments taking place along the coastal areas, large volumes of wastewater from different point and non-point sources enter the inland water bodies and end up in the sea. Discharge of massive quantities of wastewater is bound to adversely affect the coastal-marine ecosystem (Vymazal, 2008). Constructed wetlands have been proposed as wastewater treatment facilities. They help in purification of water before its discharge to the sea. A cleaner environment helps in the growth of aquatic vegetation, nutrient cycling and development of ecosystem features that provide habitat for many species (Scholz and Lee, 2005). They also capture and conserve rain water and storm water for multiple uses in addition to creating a congenial environment for the wildlife.

The initiative of Frangipani Resort in Langkawi involving construction of this sort of wetland to treat the waste water from the resort before its discharge to the environment is an example of human intervention in mitigating environmental impacts. Wong (2017) presented the design of such a facility and there are positive reviews on this project in terms of green rating metrics and Green Building Index intended for supporting the sustainable development of Langkawi.

\section{Coastal environment- challenges and management frameworks}

Malaysia's mainly agricultural economy started significantly diversifying with the rapid expansion of manufacturing infrastructure (Mokhtar et al., 2010). This was supported by various policies such as the New Economic Policy (19711990), Vision 2020 (1991-2020), National Development Policy (1991-2000) and National Vision Policy (2001-2010) among others. According to the Economic Report 2014/2015 published by the Ministry of Finance Malaysia, the manufacturing sector was projected to contribute $5.5 \%$ of the total Gross Domestic Product (GDP) in 2015, while the agricultural sector $3.1 \%$ of the total GDP in the same year (MOF, 2014).

With the manufacturing sector intensifying for economic benefits, the government introduced the Environmental Quality Act 1974 (EQA 1974) for protection of the environment through regulations aimed at reducing and eliminating the negative impact of industrialization. This Act covers different aspects of environmental protection, including pollution and contamination caused by hazardous substances. Due to industrialization and GDP contribution by the manufacturing sector, Malaysia allows the use of different types of materials and processes by the industry. However, the emissions, discharges and deposit of environmentally hazardous substances, pollutants and wastes are regulated by the Department of Environment (DOE). In this regard, EQA 1974 gives DOE the mandate to apply measures necessary for monitoring environmental impacts and controlling environmental degradation.

Accordingly, Fisheries Act 1985 is responsible for sustainable management of marine resources besides helping with the enforcement of marine reserves. Ecosystem Approach to Fisheries Management is one of the latest measures taken for rationally managing the fisheries resources. Fisheries Department depends on DOE for pollution control of coastal waters through the EQA 1974. For water resources management in Malaysia, the federal government works closely with the state governments. Better coordination is required among the federal, state and local authorities for the coastal pollution management through better implementation of policies. The engagement and participation of public, private and civil society are essential for the integrated and holistic approach towards coastal pollution management. 
Pollution from point sources can be better monitored by the local authorities. In this context, capacity building of the stakeholders will obviously help in governance of coastal pollution management at Langkawi. For this purpose, Universiti Kebangsaan Malaysia (UKM) has introduced sustainability science in course curricula and has been supporting research in this area. UKM established the Langkawi Geopark Research Station to promote the sustainable development goals. Institute for Environment and Development (LESTARI) of UKM is involved in research activities related to geological and archeological features of Langkawi in addition to local cultures, practices and biodiversity to unravel the ecological wonders of this island. LESTARI also has a good collaboration with Langkawi Development Authority and increasing engagement with the local community for growth and sustainability of Langkawi Geopark.

The main assets of Langkawi are the beaches, forests, and its status as an island with a marine ecosystem that is rich in biodiversity. Geopark is a platform for sustainable development of Langkawi through the concerted efforts of local government, indigenous communities, industry players, tourism agencies and other stakeholders. People of Langkawi are the ones who play an important role in ensuring the success of sustainable development planning.

The main attraction of Langkawi that is continuously promoted and marketed is tourism, especially the ecotourism. Langkawi Development Authority (LADA) has a five-year plan to carry out the construction and improvement of tourism-related infrastructure. LADA also collaborates and shares experiences with the relevant stakeholders, including experts and non-governmental organizations. Through awareness programs being undertaken the people are more appreciative of what LADA had done, especially for the general public, school children, and other services for the island community.

Community involvement is crucial in efforts to bring about change in behaviour of the people, and in some cases taking them away from the 'business-as-usual' way of life. It is important for the community to continue to support LADA's initiatives, and all the conservation and preservation efforts.

The challenge faced by LADA is mainly the increasing demand due to the expanding tourism industry. Cooperation of the island residents is vitally important for protecting and preserving the natural beauty of Langkawi and its ecotourism appeal. There is a need to educate the community, and this can be challenging. Generally, if the people are given the choice between what they can gain with what they need to do, their preference is for monetary benefits. The way forward for LADA is to formulate a comprehensive conservation and protection plan that focuses on creating public awareness about the Geopark and benefits that can accrue to the people from their cooperation. Geopark status has certainly contributed to making people aware of the importance of preserving and managing the island (LESTARI, 2015).
Environment and natural resources of Langkawi should be safeguarded and monitored due to the fact that it is being groomed to be the top 10 tourist destinations in the world. Number of tourist arrivals has increased from 3.06 million in 2012 to 3.62 million in 2015 (LADA, 2017). Similarly, Langkawi Global Geopark is privileged with nature-based tourism due to unique geological features, rich biodiversity, rare mangrove species as well as a rich sociocultural heritage (UNESCO, 2017). Langkawi has been a 'Low Carbon Island' and despite developments that have been taking place on the island efforts are being made to preserve this feature to provide a sense of sustainable living to the visitors. Protection of coastal vegetation, biodiversity conservation, use of electric taxi services supported by 20 vehicle-charging stations to reduce emissions (NRE, 2014; Bernama, 2017) are among the steps taken. The first commercial solar electric boat in Langkawi island contributed to 'greening' of the Island and providing a facility to visitors to venture out to explore the coastal vegetation and wildlife (JUNGLEWALLA, 2017). Langkawi Sustainability Science Demo Site of UNESCO promoted ecotourism through environmental education to conserve environment and water (UNESCO, 2017). Furthermore, the Langkawi has been identified as the Global Aquaculture Hub (Sharif, 2017) due to environmental conditions compatible for aquaculture and logistical support available. There is no reason why the island will not be able to support expansion of ecological aquaculture to supply much-needed farmed fish (Naam, 2016). A good quality aquatic environment will be prerequisite for sustainable development of aquaculture. This has to be monitored on a regular basis. Malaysia endeavors to make Langkawi a showcase of sustainable living that can inspire the visitors to practice a lifestyle that is in harmony with nature.

\section{Conclusion}

Environment and health are at the centre of human development. Achieving health and wellbeing of human society requires rational management of natural resources. A regular monitoring of environmental quality and tracking progress of regulations for sustainable development are of paramount importance. Langkawi has historically supported traditional use of land and marine resources by the indigenous communities and this has come to the forefront of scientific attention due to the many development plans being implemented there. Tourism is among the activities that have rapidly grown in Langkawi. These have put pressures on the environment, requiring decision-making bodies to take steps for bringing development within environmental thresholds. The empirical data generated by scientific investigations raises concern about contamination of coastal-marine waters of Langkawi by heavy metals and other hazardous substances. Sources of pollution and methods of mitigation as identified through intensive research should provide evidence for informed policy towards sustainable management of this island. 


\section{References}

Abdullah, N. K., Sakawi, Z. \& Ismail, L. (2014). The Perception of the Langkawi Community on Solid Waste Management. Current World Environment 9(2), 237-243.

Agusa, T., Kunito, T., Yasunaga, G. et al. (2005). Concentrations of trace elements in marine fish and its risk assessment in Malaysia. Marine pollution bulletin 51(8), 896-911.

Alam, L., Mokhtar, M. B., Alam, M. et al. (2015). Assessment of environmental and human health risk for contamination of heavy metal in tilapia fish collected from Langat Basin, Malaysia. Asian Journal of Water, Environment and Pollution 12(2), 21-30.

Alina, M., Azrina, A., Mohd Yunus, A. et al. (2012). Heavy metals (mercury, arsenic, cadmium, plumbum) in selected marine fish and shellfish along the Straits of Malacca. International Food Research Journal 19(1), 135-140.

Anishchenko, O., Sushchik, N., Makhutova, O. et al. (2017). Benefit-risk ratio of canned pacific saury (Cololabis saira) intake: Essential fatty acids vs. heavy metals. Food and Chemical Toxicology 101, 8-14.

Azevedo, J. d. S., Hortellani, M. A., Sarkis, J. E. d. S. (2012). Accumulation and distribution of metals in the tissues of two catfish species from Cananéia and Santos-São Vicente estuaries. Brazilian Journal of Oceanography 60(4), 463-472.

Bakri, M. B. (2014). Trace Heavy Metals (Cd, Cu, Pb) in Diploria Labyrinthiformis \& Favia Pallida Corals at Langkawi Island. Retrieved 4 September 2017, from

Bastidas, C., García, E. (1999). Metal content on the reef coral Porites astreoides: an evaluation of river influence and 35 years of chronology. Marine Pollution Bulletin 38(10), 899-907.

Bernama. (2017). RM3 million to kick off two low carbon projects in Langkawi. Retrieved 25 September 2017 from pressreader https://www.pressreader.com/malaysia/the-borneopost $/ 20170712 / 282183651090199$

Brown, J. E., Jones, S. R., Saxén, R.et al. (2004). Radiation doses to aquatic organisms from natural radionuclides. Journal of Radiological Protection 24(4A), A63-A77.

Chan, G. K. (2015). Social networks as social capital for eco-tourism in Malaysia: A preliminary sociological study of the Langkawi Geopark. Geografia Malaysian Journal of Society and Space 11(13), 156-164.

Chu, Y. L., Chimeddulam, D., Sheen, L. Y. et al. (2013). Probabilistic risk assessment of exposure to leucomalachite green residues from fish products. Food and chemical toxicology 62, 770-776.

EU. (2014). Science for Environment Policy, Thematic Issue: Coastal zones: achieving sustainable management (Issue 46) (Publication no. DOI 10.2779/53698). Retrieved 10 September 2014, from European Union

Ghani, S. A. A. (2015). Trace metals in seawater, sediments and some fish species from Marsa Matrouh Beaches in north-western Mediterranean coast, Egypt. The Egyptian Journal of Aquatic Research 41(2), 145-154.

Haizhou, Z. (2017). Answering the call of Langkawi. Retrieved 29 August 2017, from CHINADAILY http://chinadailyasia.com/articles/40/249/105/1503897417583.html

Hajeb, P., Jinap, S., Ismail, A. et al. (2009). Assessment of mercury level in commonly consumed marine fishes in Malaysia. Food Control 20(1), 7984.

Harvey, N. \& Caton, B. (2003). Coastal Management in Australia. University of Adelaide Press, 195 pp. University of Adelaide Press, The University of Adelaide 5005, Australia

Huntzicker, J. J., Friedlander, S. K., Davidson, C. I. (1975). Material balance for automobile-emitted lead in Los Angeles basin. Environmental Science \& Technology 9(5), 448-457.
Irwandi, J. \& Farida, O. (2009). Mineral and heavy metal contents of marine fin fish in Langkawi Island, Malaysia. International Food Research Journal 16, 105-112.

Islam, M. S., Ahmed, M. K., Raknuzzaman, M. et al. (2015). Heavy metal pollution in surface water and sediment: a preliminary assessment of an urban river in a developing country. Ecological Indicators 48, 282-291.

Jalal, K., Faizul, H. N., Kamaruzzaman, B. et al. (2009). Studies on physico-chemical characteristics and sediment environment along the coastal waters in Pulau Tuba, Langkawi, Malaysia. Aquatic Ecosystem Health \& Management 12(4), 350-357.

Jalal, K., Kamaruzzaman, B., Arshad, A.et al. (2012). Diversity and distribution of fishes in tropical estuary Kuantan, Pahang, Malaysia. Pakistan journal of biological sciences: PJBS 15(12), 576-582.

JUNGLEWALLA. (2017). Solar Boat. Retrieved 29 August, 2017, from http://www.junglewalla.com/junglewalla-solar-boat/

Kamaruzzaman, B., Rosnan, Y., Lokman, H. M. et al. (2002). Physicochemical characteristics and dissolved trace metals in the chukai river estuary, terengganu. Malaysia. Chem. Res. Commun 25, 41-51.

Kamaruzzaman, B., Shuhada, N., Akbar, B. et al. (2011). Spatial concentrations of lead and copper in bottom sediments of Langkawi Coastal Area, Malaysia. Research Journal of Environmental Sciences 5(2), 179 . 186.

Kamaruzzaman, B., Shuhada, N., Zahir, M. et al. (2011a). Concentrations of Lead, Copper and Zinc in the Bottom Sediments of Tuba Island Waters of Langkawi, Malaysia. Oriental Journal of Chemistry 27(2), 505-510.

Kamaruzzaman, B., Willison, K., Ong, M. (2006). The concentration of Manganese, Copper, Zinc, Lead and Thorium in Sediments of Paka Estuary, Terengganu, Malaysia. Pertanika Journal of Science and Technology 14(1), 53-61.

Kinsella, J. E., Lokesh, B. \& Stone, R. A. (1990). Dietary n-3 polyunsaturated fatty acids and amelioration of cardiovascular disease: Possible mechanisms. American Journal of Clinical Nutrition 52(1), 1-28.

LADA (2017). Background. Reteieved 25 September 2017 from Langkawi Development Authority https://www.lada.gov.my/en/information/langkawi-tourismblueprint/bpl-background

Lee, J. \& Mohamed, C. A. R. (2009). Trace Metal Contents in the Porites Corals of Peninsular Malaysia. International Journal of Environmental Research 3(1), 85-94.

LESTARI. (2015). Sustainability Science for Sustainable Development Goals (SDGs). Special Technical Report. Universiti Kebangsaan Malaysia, Selangor, Malaysia. Retrieved 11 September 2017, from Institute for Environment and Development http://www.ukm.my/lestari/doc/report_ss2015.pdf

Lundy, L., Alves, L., Revitt, M. et al. (2017). Metal water-sediment interactions and impacts on an urban ecosystem. International Journal of Environmental Research and Public Health 14(7), 722. DOI: 10.3390/ijerph14070722.

Mirsadeghi, S. A., Zakaria, M. P., Yap, C. K. et al. (2011). Risk assessment for the daily intake of polycyclic aromatic hydrocarbons from the ingestion of cockle (Anadara granosa) and exposure to contaminated water and sediments along the west coast of Peninsular Malaysia. Journal of Environmental Sciences 23(2), 336-345.

MOF. (2014). Economic Report 2014/2015: Ministry of Finance Malaysia.

Mohiuddin, K., Ogawa, Y., Zakir, H. et al. (2011). Heavy metals contamination in water and sediments of an urban river in a developing country. International Journal of Environmental Science \& Technology $8(4), 723-736$ 
Mokhtar, M. B., Ta, G. C. \& Murad, M. W. (2010). An essential step for environmental protection: Towards a sound chemical management system in Malaysia. Journal of Chemical Health and Safety 17(5), 13-20.

Mokhtar, M., Awaluddin, A., Tan, M. et al. (2001). Trace Metals in Langkawi coral and sediment: a study using AAS and XRF. Malaysian J. Anal. Sci 7(1), 189-196.

Naam. (2016). Fishcage business set to become a tourism boom in Langkawi. Retrieved 25 September 2017 from Naam Sdn. Bhd. https://www.naam.bz/blog/news/fishcage-business-set-to-become-atourism-boom-in-langkawi-

NRE. (2014). Feasibility Study for the Development of Low Carbon Island Model for Langkawi Island. Retrieved 25 September 2017 from Ministry of Natural Resources and Environment http://www.nre.gov.my/sites/lecbnre/Pages/NAMA-Activity3.aspx

Oomen, C. M., Feskens, E. J. M., Räsänen, L. et al. (2000). Fish consumption and coronary heart disease mortality in Finland, Italy, and the Netherlands. American Journal of Epidemiology 151(10), 999-1006.

Prohl, G. (2003). Dosimetric Models and Data for Assessing Radiation Exposures to Biota. Special Technical Report. Norwegian Radiation Protection Authority, Osteras: Deliverable 3 to the Project FASSET Framework for the Assessment of Environmental Impact.

Retnam, A., Zakaria, M. P., Juahir, H. et al. (2013). Chemometric techniques in distribution, characterisation and source apportionment of polycyclic aromatic hydrocarbons (PAHS) in aquaculture sediments in Malaysia. Marine pollution bulletin 69(1), 55-66.

Scholz, M. \& Lee, B. H. (2005). Constructed wetlands: a review. International journal of environmental studies 62(4), 421-447.

Shamshiry, E., Nadi, B., Mokhtar, M. B. et al. (2012). Impact of landfill leachate on water quality in Langkawi Island using management of environmental system. Asian Journal of Chemistry 24(5), 1919-1923.

Sharif, A. (2017). Langkawi set to become aquaculture hub in Asean region by 2018. Retrieved 25 September 2017 from New Straits Times https://www.nst.com.my/news/nation/2017/09/278375/langkawi-setbecome-aquaculture-hub-asean-region-2018

Shen, G. T. \& Boyle, E. A. (1987). Lead in corals: reconstruction of historical industrial fluxes to the surface ocean. Earth and Planetary Science Letters 82(3-4), 289-304.

Stocker, L., Kennedy, D., Kenchington, R. et al. (2012). Sustainable coastal management. In: Sustainable Coastal Management and Climate Adaptation, Global Lessons from Regional Approaches in Australia (R. Kenchington, L. Stocker, L., \& D. Wood, eds.), pp 29-56. Csiro Publishing, Collingwood, Australia

Strandberg, U., Palviainen, M., Eronen, A. et al. (2016). Spatial variability of mercury and polyunsaturated fatty acids in the European perch (Perca fluviatilis)-Implications for risk-benefit analyses of fish consumption. Environmental Pollution 219, 305-314.

Tajam, J. \& Kamal, M. L. (2013). Marine environmental risk assessment of Sungai Kilim, Langkawi, Malaysia: heavy metal enrichment factors in sediments as assessment indexes. International Journal of Oceanography 2013, http://dx.doi.org/10.1155/2013/482451

Taweel, A., Shuhaimi-Othman, M. \& Ahmad, A. (2013). Assessment of heavy metals in tilapia fish (Oreochromis niloticus) from the Langat River and Engineering Lake in Bangi, Malaysia, and evaluation of the health risk from tilapia consumption. Ecotoxicology and environmental safety 93, 45-51.

UKEssays. (2015). River Water Pollution at Langkawi Island Environmental Sciences Essay. Retrieved 29 August 2017, from UKEssays

UNESCO. (2017). Sustainability Science Demonstration Site 1: Langkawi, Malaysia. Retrieved 25 September 2017 from UNESCO Office Jakarta http://mucp-mfit.org/knowledge-platform-sustainability-sciencedemonstration-site-1-langkawi-malaysia/
United Nations. (2017). Sustainable Development Goal 14. Retrieved 10 $\begin{array}{lllll}\text { September } & 2017 & \text { from } & \text { United }\end{array}$ https://sustainabledevelopment.un.org/sdg14

Vilavert, L., Borrell, F., Nadal, M. et al. (2017). Health risk/benefit information for consumers of fish and shellfish: FishChoice, a new online tool. Food and Chemical Toxicology 104, 79-84. https://doi.org/10.1016/j.fct.2017.02.004

Vymazal, J. (2008). Constructed wetlands for wastewater treatment: a review. Paper presented at the Proceedings of Taal 2007: The 12th World Lake Conference.

Wong, A. (2017). Constructed Wetlands, A Passive Low-Cost Way Using Nature/Bio Engineering to Treat Black and Grey Water-A Passive Solution. Paper presented at the Waste Water Recycling and New Tax Incentive for Green Buildings, Bangsar, Kuala Lumpur, Malaysia, 26 July 2017.

Wong, R., Chun, F. C. \& Wong, H. W.(2005). Distribution of Heavy Metals Found in Three Major Rivers of North-Eastern Pulau Langkawi. Malaysian Journal of Science 24(3).

Wood, A. K. H., Ahmad, Z., Shazili, N. A. M. et al. (1997). Geochemistry of sediments in Johor Strait between Malaysia and Singapore. Continental Shelf Research 17(10), 1207-1228.

Yap, C. K., Ismail, A., Tan, S. G. (2003). Background concentrations of Cd, $\mathrm{Cu}, \mathrm{Pb}$ and $\mathrm{Zn}$ in the green-lipped mussel Perna viridis (Linnaeus) from Peninsular Malaysia. Marine Pollution Bulletin 46(8), 1044-1048. doi: Doi: 10.1016/s0025-326x(03)00163-2

Yap, C., Ismail, A., Tan, S. (2003a). Cd and Zn concentrations in the straits of Malacca and intertidal sediments of the west coast of Peninsular Malaysia. Marine Pollution Bulletin 46(10), 1349-1353.

Yap, C., Ismail, A., Tan, S. (2003b). Mercury levels in the green-lipped mussel Perna viridis (Linnaeus) from the West Coast of Peninsular Malaysia. Bulletin of environmental contamination and toxicology 71(3), 05700576 .

Yap, C., Ismail, A., Tan, S. et al. (2002). Concentrations of $\mathrm{Cu}$ and $\mathrm{Pb}$ in the offshore and intertidal sediments of the west coast of Peninsular Malaysia. Environment International 28(6), 467-479.

Yu, Y., Wang, X., Yang, D. et al. (2014). Evaluation of human health risks posed by carcinogenic and non-carcinogenic multiple contaminants associated with consumption of fish from Taihu Lake, China. Food and Chemical Toxicology 69, 86-93.

Zahir, M. M., Kamaruzzaman, B., John, B. A. et al. (2011). Bioaccumulation of selected metals in the blood cockle (Anadara granosa) from Langkawi Island, Malaysia. Oriental Journal of Chemistry 27(3), 979984

Zakaria, M. P., Takada, H., Tsutsumi, S. et al. (2002). Distribution of polycyclic aromatic hydrocarbons (PAHs) in rivers and estuaries in Malaysia: a widespread input of petrogenic PAHs. Environmental science \& technology 36(9), 1907-1918.

Zulfigar, Y., Jamil., T., Shahima, A. H. et al. (2013). Marine Biodiversity Expedition Report 2012: Northern Straits of Malacca -Payar and Songsong Islands Archipelago (Vol. 1). 